\title{
Martin Bylica at the Court of Matthias Corvinus: Astrology and Politics in Renaissance Hungary
}

\author{
DARIN HAYTON*
}

\begin{abstract}
Matthias Corvinus, King of Hungary from 1458-1490, recognized an intimate connection between astrology and politics. His rich library contained numerous astrological texts, and he decorated his palaces at Buda and Visegrád with horoscopes. He also provided generous patronage for foreign astrologers. One of the most famous astrologers to spend his career at Corvinus's court was Martin Bylica. Bylica had been trained in astrology at the University of Krakow before moving, eventually, to Hungary. By 1468, Bylica had attracted Corvinus's attention and began to benefit from the king's generous patronage. Bylica provided Corvinus with important political and military advice throughout the king's reign. Equally important, Bylica's career in Buda helped to construct the image of Corvinus as a Renaissance monarch who drew on the most sophisticated sciences available in the fifteenth century.
\end{abstract}

Late in the spring 1468, Matthias Corvinus convened the Hungarian diet in the city of Pozsony. Holding the diet in Pozsony enabled him to impress the Hungarian nobles with the local intellectual community that had begun to form at his fledgling Academia Istropolitana, which he had founded the previous year. Pozsony was also conveniently located close to Moravia, where Corvinus had recently initiated hostilities against the governor. The diet had a number important domestic and foreign political issues to resolve. Corvinus's relations with the Bohemian king, George of Podebrady, had always been strained. Following the death of Corvinus's wife, Catherine Podebrady in 1464, tensions had increased (Odložilík 1965, pp. 190-221; Engel 2001, p. 304). Corvinus had in March 1468 declared war on Victorin Podebrady, the Bohemian king's son and governor of Moravia, and had more recently invaded southern Moravia. In addition to the hostilities in Bohemia, Corvinus had to contend with domestic unrest, centered largely around his financial reforms and taxation. In the fall 1467, he had been forced to lead an army into Transylvania to quell a rebellion of barons there. In December, he had been defeated by Prince Stephen in Moldavia when he had tried to force the prince's allegiance. Corvinus's hold on the Hungarian throne was certainly not secure.

Along with these pressing military and diplomatic issues, Corvinus had scheduled a disputation between two Polish astrologers: Martin Bylica and Jan Stercze. Stercze had been Bylica's student and was now the court astrologer to János Rozgon, a Hungarian count

\footnotetext{
*History Department, Haverford College, 370 Lancaster Avenue, Haverford, Pennsylvania 19041, USA. E-mail: dhayton@haverford.edu
} 
with close ties to Corvinus's court. The debate between these two astrologers centered on a nativity horoscope that Stercze had constructed for the birth of Rozgon's son. Rozgon had asked Bylica to confirm the horoscope and Stercze's interpretation. Bylica concluded that Stercze's calculations were faulty and that his understanding of key astrological principles was flawed. The two astrologers carried out their dispute in a series of letters leading up to the diet in Pozsony. In front of Corvinus, Rozgon, and the rest of the assembled counts and barons, Bylica and Stercze debated the proper astrological techniques and appropriate methods of interpretation (Bylica n.d.; Pułaski 1915, pp. 43-45). At first glance, astrological technique might seem only remotely related to political practice. In the latter 15 th century, however, astrology was central to the practice of politics (Carey 1992; Smoller 1994; Azzolini 2005; Mentgen 2005).

In Bylica's own account of the debate, Stercze 'was mocked and scorned both by our lord King Matthias and by Lord Rozgon', who had immediately recognized Stercze's errors (Bylica n.d., f. 146v). ${ }^{1}$ When Corvinus judged the dispute, he declared Bylica the winner and awarded him 100 florins. More importantly, Bylica became Corvinus's principle political advisor. Bylica's success is further testified by a letter Corvinus wrote shortly after the diet ended. Corvinus had returned to Moravia to continue his military offensive. In July, he besieged the town of Hradište in southern Moravia but had failed to capture it. On 25 July, Corvinus sent a letter to Pozsony instructing the town council to provide Bylica with a coach, horses, and any provisions necessary so that he could journey immediately to Hradište to advise the king. In a prescient comment, Corvinus refers to Bylica as his 'master Martin, astronomer and Galeotus' (Corvinus 1468, p. 351). ${ }^{2}$ Corvinus had identified Bylica as a Galeotus, alluding to the Sicilian interpreters of prodigies, 2 months before Bylica himself interpreted for the king a prodigious comet (Cicero 1923, Book 1, chap. 20, 39). ${ }^{3}$

The debate between Bylica and Stercze brings into sharp focus the importance of astrology in the political practice in Renaissance Hungary. The academic dispute between these two astrologers was dragged into the powerful world of royal politics precisely at a time when Corvinus and the diet had important domestic and foreign problems. Indeed, the fact that their contest was an important event at the diet in 1468 locates astrology at the center of Corvinus's politics and highlights the king's own interest in astrology.

Modeling himself on other Renaissance princes, Corvinus drew on a wide range of intellectual and artistic practices to construct his image and to transform the institutions of government in 15th-century Hungary. He adopted the Italian Renaissance styles in architecture when he renovated his palaces and gardens at Buda and Visegrád (Rosenthal 1978, p. 35; Buzás 2001). In addition to his interest in Renaissance architecture, Corvinus was a wealthy patron of the visual and plastic arts (Balogh 1966; Balogh 1975; Feuer-Tóth 1990; Kaufmann 1995, pp. 40-45; Engel 2001, pp. 318-322). Most famously, the king developed an immense library of richly illuminated Greek and Latin manuscripts (Berkovits 1964; Berkovits 1969; Csapodi and Csapodi-Gárdonyi 1969; Rady 2004). Corvinus's library was not simply a collection of books. It was, instead, a working collection intended 
for the glory of the kingdom (Csapodi and Csapodi-Gárdonyi 1969, pp. 31, 52; Rady 2004, p. 95). Visiting and residential scholars consulted the books and emended them. The library also functioned as a propaganda tool (Rady 2004, p. 95). The library was, then, important both as an ideal and as a functioning library, which revealed the king's own intellectual and dynastic interests.

The contours of Corvinus's library reveal a patron deeply interested in astrology and astronomy. His collection included Greek and Latin classics, such as Julius Firmicus Maternus's Matheseos libri octo. Corvinus also collected recent translations of important works, including George of Trebizond's translation of Ptolemy's Almagest. Alongside these classic works in astrology stood texts by contemporary authors. The German astronomer Regiomontanus is well represented. Lesser-known figures, such as Johannes Tolhopff, also appeared in Corvinus's library (Thorndike 1936). Corvinus also collected Byzantine manuscripts on astrological instruments (Csapodi and Csapodi-Gárdonyi 1969, pp. 372-373). Corvinus's efforts to incorporate astrology into his politics extended well beyond the walls of his famous library. He struggled to attract and retain the best astrologers. The career of Martin Bylica illustrates the extent to which Corvinus relied on astrological advisors and illuminates a key facet of Corvinian politics, a facet that has largely escaped attention (one brief exception to this is Vargha and Both 1987).

Martin Bylica from Olkusz matriculated at the University of Krakow in the winter semester 1452. As a student, he probably heard lectures by Andreas Grzymałas, who held the chair in astrology and mathematics at the university. The University of Krakow was the only university in central Europe with a chair in astrology. In 1452, the astrologer Martin Król from Żurawica had established this chair along with a chair in mathematics in order to promote the study of astrology and mathematics at the university (Birkenmajer 1972b, pp. 455-459; Markowski 1973, p. 125). When Bylica received his bachelor's degree in 1456, he began holding lectures on astronomical subjects, including the compotus literature. Three years later, he received his master's degree and was probably promoted to the chair in astrology and mathematics. As the holder of this chair, he would have lectured on Ptolemy's Quadripartitum and Centiloquium as well as Abumasar's Introductorium (Birkenmajer 1972c, p. 533; Markowski 1989, pp. 125-126). By 1462, Bylica had left Krakow to study medicine at the University of Bologna. At Bologna, Bylica also held lectures on astrology in 1463/1464 and quickly distinguished himself as a excellent astrologer and learned master (Dallari 1888, p. 64; Birkenmajer 1892, p. 102). Bylica's reputation as an excellent astrologer soon attracted the attention of Cardinal Rodericus Borgia, who appointed Bylica his court astrologer.

In the summer 1464, Bylica accompanied the Borgia to Rome to participate in the Papal Conclave. Once there, Bylica befriended Regiomontanus, who was in Rome working as the court astrologer for Cardinal Bessarion. Regiomontanus composed his Dialogus inter Viennensem et Cracoviensem adversus Gerardum Cremonensem in planetarum theoricas deliramenta in August. He constructed the dialog around a series of discussions between Johannes from Vienna and Martin from Krakow, clear allusions to himself and 
Bylica (Regiomontanus 1474). The two characters explore the problems with Gerard of Cremona's Theorica planetarum and suggest ways of improving the text (Kren 1977; Swerdlow 1990).

That fall the brilliant Hungarian humanist Janus Pannonius was in Rome to celebrate the new pope and to seek a papal charter for the founding of a university in Hungary. Pannonius's uncle, Johannes Vitéz, had persuaded Corvinus to establish a university in Pozsony, which would provide the Hungarian courts with a local pool of humanists and scholars. Initially, however, there were insufficient numbers of scholars in Hungary to staff even a small university. And although Vitéz's and Pannonius's courts had attracted a few humanists, there were no astrologers or astronomers of any renown in Hungary. Pannonius took advantage of the confluence of cardinals, with their richly supported courts, to recruit astrologers and mathematicians to the new university. On 19 May 1465, Pannonius received the papal charter for a university in Pozsony and, at the same time, succeeded in convincing Regiomontanus and Bylica to move to Hungary to take up the chairs in mathematics and astrology at the new university.

Regiomontanus and Bylica did not move immediately to Pozsony. Instead, they spent more than a year at Vitéz's palace in Esztergom, where they collaborated on a various projects. Recognizing Corvinus's interest in astrology, they first produced Regiomontanus's Tabulae directionum profectionumque, an astrological text that Regiomontanus dedicated to Corvinus. Bylica added a note to the front of his copy of this text, explaining that he 'was present and assisted in numerous places' in the completion of this text (Regiomontanus 1467, n.p.). ${ }^{4}$ Bylica's annotations and glosses throughout the text seem to support his claim (Regiomontanus 1467). A similar collaborative effort was probably responsible for Regiomontanus's two other texts produced at this time: his Tabulae ac problemata primi mobilis and his Tabula sinuum. Bylica glossed and emended his copies of both these texts (Regiomontanus n.d.; Regiomontanus 1468).

When the two finally arrived at Pozsony in July 1467 to celebrate the opening of the university, the city spared no expense in welcoming the masters (Gabriel 1969, pp. 37-50). One of Bylica's first tasks was to cast the horoscope for the opening of the university on 5 June 1467 (Bylica 1467, f. 212r.). The horoscope was added to the last page of Corvinus's copy of Ptolemy's Almagest. Bylica did not record his interpretation of the chart, but he did indicate the general tenor of his interpretation. Noting that Mercury was in the twelfth house, Bylica claimed that 'Anyone who has Mercury in the twelfth house will be extremely wise and great philosopher' (Bylica 1467, f. 212r). ${ }^{5}$ Bylica was probably hoping to reassure Corvinus that his new university would succeed and would, perhaps, even rival the University of Vienna just up the Danube. For the next year, Bylica lectured on astrology at the university and engaged in the dispute with his former student, Jan Stercze. Then, in the summer 1468, Bylica and Stercze held their famous debate before the Hungarian diet in Pozsony. Bylica's success in this debate ensured his position at the Hungarian court, where he would spend the remainder of his career. 
The comet that appeared on 22 September 1468 provided Bylica the perfect opportunity to fulfill Corvinus's expectations when he had called Bylica a Galeotus. Bylica was back in Pozsony holding lectures at the university when he observed the comet. He quickly composed his judicium on the comet in which he interpreted the prodigious phenomenon for his patron. On 6 October, Bylica dedicated his tract to Corvinus, hoping to honor and to reassure him that this comet portended favorable events (Bylica 1468b, f. 113v). Bylica made his commitment to the king clear in the opening lines of his text, where he wrote

Because I know that your majesty, most serene prince, desires nothing more than the health of your kingdom, the care and governance of which God has recently placed in your hands, I myself decided to explain to you my judgement of things to come from this comet to which I will add the arguments of the most learned astrologers and things learned from experience (Bylica 1468b, f. 107r). ${ }^{6}$

Bylica then praised Corvinus, calling him an unparalleled master, the most excellent and famous king of Hungary and most meritorious defender of the Christian religion (Bylica $1468 \mathrm{~b}, \mathrm{f} .107 \mathrm{r}$ ). Bylica's last accolade was no mere platitude. It was, rather, calculated to reflect and reinforce Corvinus's own image as the true defender of the Catholic Church, particularly in the face of the Utraquist king of Bohemia, George Podebrady.

For more than two decades, Podebrady had been consolidating his power in Bohemia. After being elected King of Bohemia in 1458, Podebrady had made various efforts to reconcile Bohemia with the Papacy. In the late 1450s, he had subjugated the more radical Hussites, but he refused to abandon his own Utraquist beliefs. In the early 1460s, however, Podebrady's efforts to establish agreement between Bohemian Catholics and Utraquists began to unravel, forcing him to favor his Hussite supporters over the Catholic nobles. Podebrady was preoccupied with domestic problems and neglected his relations with the Holy See until 1462, when he sent a delegation to Rome petitioning for the compactata from the Council of Basel. Pope Pius II rejected the petition and demanded that Podebrady give up his Utraquist beliefs and enforce Catholic orthodoxy in Bohemia. Podebrady refused and instead began appointing Utraquist supporters to important governmental offices and, further, attempted to establish a union of princes free from papal control. This union never materialized, but Podebrady's diplomatic efforts were sufficient to provoke the pope into action. After the election of Pope Paul II in August 1464, the situation worsened. Paul adopted a strict position on Podebrady and the Bohemian problem and summoned Podebrady to Rome to answer charges of heresy. When Podebrady failed to appear before the Papal court, Paul excommunicated the king in December 1465. A year later Paul declared Podebrady a heretic and charged Corvinus with deposing him. Urged on by the pope, Corvinus declared himself the savior of Bohemian Catholics and defender of the true church. In early 1468, when Victorin Podebrady attacked Austria, Corvinus seized the opportunity to declare war on Bohemia and to invade Moravia. Corvinus clothed his aggression in the guise of a crusade to defend the true faith, a preview to his crusade against the Turkish infidel (Odložilík 1941; Odložilík 1965, pp. 476-511; Engel 2001, pp. 302-306).

Such was the context for Bylica's Judicium de cometa que apparavit Anno Domini Mcccc $68 .^{7}$ Bylica aligned his rhetoric with the image that Corvinus was trying to project. 
After praising, Corvinus Bylica pointed out that he was not only going to discuss future events but also the

swift death of that most sinful heresiarch George of Podebrady, who holds himself up as king of Bohemia, Poderbad the most severe enemy of the orthodox faith and the Roman Church. To defend the Catholic faith, Your Majesty has begun a war with him in the present year (Bylica 1468b, f. $107 \mathrm{r}){ }^{8}$

Corvinus's efforts to portray himself as a crusader had found an eager supporter in Bylica, who clearly understood his judicium as part of the king's efforts to drive Podebrady from the Bohemian throne. Bylica's judicium functioned on multiple levels. First, it reassured Corvinus that his offensive in Moravia and his efforts to gain the Bohemian throne would be successful. Bylica's judicium also functioned as a timely piece of propaganda for the king who rarely missed an opportunity to hold himself up as the defender of Christendom. Corvinus's propaganda program sought to secure the pope's financial support and to elicit sympathy from European princes (Engel 2001, p. 303). Finally, capitalizing on his successful advice during Corvinus's siege of Hradište - the town had fallen shortly after Bylica's arrival-Bylica used his judicium to reinforce his own role in Corvinus's Bohemian campaign. By virtue of being able to predict what would happen in Corvinus's conflict with Bohemia, Bylica had made himself indispensable to Corvinus.

Bylica adopted a traditional format for his judicium, introducing first the observational data, discussing the nature of comets in general, and finally interpreting the observations of this particular comet (a representative sample of earlier cometary tracts is found in Thorndike 1950). His judicium does not reflect an increased concern with observational precision that marked other 15th-century cometary treatises (Jervis 1985). Instead, he determined precisely when and where the comet first appeared and then mentioned briefly its path through the zodiac: "the comet appeared first near the beginning of Leo, conjoined with respect to its latitude to Jupiter and then through its own proper motion it infected the whole sign of Leo and the whole sign of Virgo' (Bylica 1468b, f. 107v). ${ }^{9}$ Bylica used this information to determine the comet's complexion and general effects. The comet, he claimed, was largely of the nature of Saturn, black in color and cold. Its tail, however, extended north toward the seven stars in Ursa Major and shared with them a rich cerulean blue color (Bylica 1468b, f. 108v). This material provided the fodder for Bylica's specific predictions of the calamities and disasters caused by the comet.

Since antiquity, comets had been interpreted as perilous portents, causing or at least signaling droughts, famines, wars, diseases, and earthquakes (Jervis 1985, pp. 11-33; Genuth 1997). Bylica was completely traditional in his general warnings. Unsurprisingly, he emphasized the characteristics of the comet that foreshadowed the death of a king and the destruction of his realm. This interpretation, Bylica assured Corvinus, was supported by both the historical record and the numerous authorities. He recounted the calamities that had followed previous comets. The comet of 1444 had foreshadowed an earthquake later that year. Then, in November, Vladislaus III, king of Poland and Hungary, along with many of his barons had been overthrown and killed by the Turks (Bylica 1468b, f. 109v). 
The comet of 1456 was similarly followed by earthquakes. 'Thus, without a doubt, our comet will be followed by earthquakes in places ruled by the sign of Leo', resulting in the destruction of many cities, towns, and castles (Bylica 1468b, f. 109v). ${ }^{10}$ In light of Corvinus's efforts to associate himself with the lion and all its characteristics, Bylica's prediction could be read as a metaphor and favorable omen for Corvinus's campaign in Moravia (Békés 2004). When he turned to his argument from authority, Bylica cites Aristotle, Pliny, Ptolemy, Haly Abenragel, John of Damascus, and Leopold of Austria, all of whom confirm that comets portend wars, famines, droughts, the deaths of kings, and the overthrow of kingdoms (Bylica 1468b, ff. 108v-109r). Bylica relied heavily on Ptolemy's Quadripartitum to support once again his prediction that cities, towns, and castles under the influence of Leo would be destroyed (Bylica 1468b, f. 109r). Bylica's unusual reference to Homer alongside the more typical authorities was probably an attempt to forge connections between different aspects of Corvinus's larger political and intellectual project. Comets in Leo, he supposedly learned from Homer and Haly Abenragel, 'indicate wars between kings and immense bloodshed' (Bylica 1468b, f. 109r). ${ }^{11}$ Bylica certainly had the conflicts between Corvinus and Podebrady in mind here.

Bylica devoted the bulk of his text to specific predictions about Pope Paul II, Emperor Frederick III, various European monarchs, and the Turks. Only in the case of Hungary did Bylica's prediction approach neutrality. Corvinus alone among the European monarchs, if he was diligent and careful, could hope to avoid serious injury or illness (Bylica 1468b, $\mathrm{f}$. 111r). Every other ruler would be plagued by mortal dangers and life-threatening sickness. The Turkish infidel, who warranted only a few lines in Bylica's judicium, could expect many unfortunate events and widespread death (Bylica 1468b, f. 111v). These predictions were banal in their general rhetoric of misfortune. They were not, however, devoid of intellectual content or political significance. In each case, Bylica constructed an argument based on the position of the comet and relevant characteristics of the horoscopes for important moments in a ruler's life. His prediction for the pope was typical of his method. Bylica opened his prediction for the pope with the general warning that the Paul II had to fear death or mortal danger because the comet appeared near Jupiter, which rules spiritual people. Moreover, Bylica argued, the comet appeared in the tenth house of the pope's election chart. Further, at the time of the comet's appearance, the sun was in the same fiery sign it had been in at the time of the pope's coronation. The dire implications of these disastrous correlations were reinforced by the fact that the comet appeared in the ascending sign of the pope's geniture. Finally, the comet appeared in the earth sign that ruled Italy and was especially threatening to Rome itself (Bylica 1468b, f. 110v). Through the rigor and complexity of his analysis, Bylica invested his prediction with an authority that was difficult to question. To make his prediction for Pope Paul II, Bylica had to construct horoscopes for the pope's election, his coronation, and his birth. He expended similar effort in his predictions for the other European princes. As foreboding as his predictions for the pope and other princes were, Bylica's main targets were Podebrady and his Utraquist priest John of Rokycany. 
Bylica had saved his real vitriol for the Bohemian heretics. He first constructed a historical narrative that enlisted comets as key religious portents. He reminded Corvinus of the comet in 1410, which had the nature of Mercury and had appeared near Jupiter in the sign of Leo. Bylica boldly asserted that the comet had killed the Bohemian king Wenceslaus and had caused the Wycliffe heresy to spread through Bohemia, largely through the teachings of Jan Hus (Bylica 1468b, f. 112r). In Bylica's narrative, the comet of 1410 had sown the seeds of heresy that had now produced two new heretics: George Podebrady and his dynamic Utraquist priest John of Rokycany. Having established the close relation between comets and political and religious changes, Bylica thought that he had good reason to predict that the comet of 1468 would bring about Podebrady's and Rokycany's ruin and death. Indeed, his predictions for Bohemia are the most specific and condemning: "clearly the condemned heretic George Podebrady, who acts as if he is the king of Bohemia and who had, at the hour of his coronation, Leo as the ascending sign,... and Rokycany, the seducer of Bohemia will be killed by this comet' (Bylica 1468b, f. 111v112r). ${ }^{12}$ Moreover, Bylica asserted, no one could possibly doubt that this comet promised not only the deaths of the heretics but also the annihilation of the entire Utraquist sect and Bohemia's return to the Catholic faith. Bylica's judicium must have reassured Corvinus. By the end of the year, the king had conquered Moravia and much of Silesia. Then, in May 1469, the Catholic nobles in Bohemia had secured Corvinus's election as king of Bohemia (Engel 2001, p. 304).

Three years later, on 17 January 1472, when Bylica composed his next tract on a comet, the political situation had changed in important ways (Bylica 1472, ff. 319r-325r). Podebrady and Rokycany had recently died, and the heresy in Bohemia seemed to have stalled. Corvinus's interest in his Bohemian campaign had been displaced by domestic unrest. A significant contingent of Hungarian magnates, including Corvinus's former supporters Pannonius and Vitéz, had grown disillusioned with Corvinus's rule and his aggression against Bohemia. Their efforts to elect Casimir of Poland to the Bohemian throne forced Corvinus to turn his attention back to quelling yet another domestic rebellion. Bylica's personal situation too had changed. In 1471, the University of Pozsony had effectively closed. Bylica's close friend and colleague Regiomontanus had relocated to Nuremberg while Bylica had moved to Corvinus's court at Buda. With his move to the court, Bylica was more secure in his relationship with Corvinus and dispensed with the flattery that had characterized his earlier text. Instead, he opened his tract with a brief indication that he was writing for Corvinus and then launched into a discussion of the details of the comet.

Once again, Bylica divided his tract into four chapters, beginning with a more sophisticated discussion of the causes of comets (Bylica 1472, f. 319v). His description of the comet's location, color, and complexion, which occupied the second chapter, reflected a greater attention to detail, though Bylica remained most interested the basic astrological information: the comet had appeared in the sign of Libra, the comet's ruddy color, and the direction of the comet's tail (Bylica 1472, ff. 319v-320r). The longest chapter contained Bylica's specific predictions regarding the calamities caused by this most recent 
comet, predictions that he defended through detailed accounts from authorities as well as experience. Once again, Bylica intended to reassure Corvinus that his conflicts would end favorably. Drawing on Ptolemy's Quadripartitum and his Centiloquium, Bylica detailed how the comet threatened kings of countries who had the comet in unfavorable aspects in their own horoscopes. Moreover, Bylica assured Corvinus, powerful nobles in countries ruled by Libra were at risk of being imprisoned and losing their lives (Bylica 1472, f. 322v). Without naming any of Corvinus's opponents, Bylica was clearly directing his dire predictions at the barons and princes who were conspiring against Corvinus. To his argument from authority, Bylica was able to add evidence from recent history. Writing in mid-January 1472, Bylica appropriated the deaths of both Podebrady and Rokycany for his new prediction. He reminded Corvinus that Bylica himself had predicted their deaths in his previous tract and thus extended his astrological narrative into the present (Bylica 1472 , fol 324v). More importantly, the accuracy of his previous prediction endowed his current text with greater authority.

Bylica was not content to consider only the fates of the Hungarian rebels. He also looked beyond the borders of Hungary and directed his attention in particular to the fates of Emperor Frederick III and of Austrian towns, which rarely fared well. Bylica asserts that cities such as Vienna and Salzburg, and indeed Austria in general, would suffer gravely because they were under the influence of the zodiacal sign of Libra, the sign in which the comet had appeared. Similarly, Frederick III, the Holy Roman Emperor, was singled out and subjected to a rather harsh judgement (Bylica 1472, ff. 323r-323v). Although Corvinus would not initiate hostilities against Frederick III for another 3-5 years, it seems clear that Bylica had already shifted his focus from Bohemia and had set his sights on Austria.

As Corvinus's principle advisor, Bylica was called on to produce more than the occasional judicium. Bylica compiled a huge collection of horoscopes for significant events in Corvinus's life, the history of the kingdom, and the lives of the king's family and enemies. He cast a chart for the founding of Hungary on 16 March 767. Underneath this chart, Bylica wrote 'Libra is the sign for the kingdom of Hungary' (Bylica n.d., f. 19r). Apparently, he did not notice the tension between this claim and his predictions for the effects from the comet in 1472, which was supposed to have the gravest effects in kingdoms ruled by Libra. Bylica's geniture for Corvinus was remarkably detailed, as was his chart for Corvinus's election in 1458 and his coronation in 1464 after Emperor Frederick III had finally returned the Hungarian crown, which cost Corvinus 80,000 ducats (Bylica n.d., ff. 8v-9r). Bylica also cast charts for Corvinus's illegitimate son Johannes and for Corvinus's second wife Beatrix (Bylica n.d., ff. 9v, 16v). Like his judicia on the comets, Bylica understood his horoscopes within Matthias's political ambitions. In 1482, Bylica cast an election for Corvinus's third campaign against Emperor Frederick III. Bylica assured Corvinus that the king's offensive would be strengthened by the superior planets, Saturn, Jupiter, and Mars (Bylica n.d., f. 11r). ${ }^{13}$ The following year, Bylica analyzed Frederick's natal chart to bolster Corvinus's offensive against the empire. Bylica pointed out that in his corrected geniture, it was clear that the Frederick's ascendent was square to the 
moon, which helped explain Frederick's military failures. In particular, Bylica pointed to the siege of Vienna 1462, when Frederick was besieged by his brother's troops and was forced to seek shelter in the Hofburg in Vienna. Bylica also used this chart to explain Frederick's losses to Corvinus in 1483 (Bylica n.d., f. 13r). Two years before Corvinus occupied Vienna, Bylica's predictions about Frederick's vulnerability must have reassured the king of his future successes. Corvinus had clearly come to rely on Bylica, who boasted in a letter to a Hungarian prelate that he, Bylica, accompanied the king whenever he left the court at Buda and especially when he went into battle (Bylica 1468a, pp. 282-284).

Bylica's close relationship with the Hungarian king continued until Corvinus's death in 1490, when Bylica added a note to the king's geniture: 'Causes of death include a conjunction of Jupiter and Mars at 16 degrees of Capricorn; also a conjunction of Mars and Mercury at 8' (Bylica n.d., f. 8v). ${ }^{14}$ Bylica was not the only significant astrologer to spend time in Hungary. Jan Stercze, Bylica's former pupil and opponent at the diet in 1468, had been active at Rozgon's court and was probably hoping that a successful performance in the debate against Bylica would ensure him a position at Corvinus's court. When he lost, he apparently remained in Hungary working for lesser nobles in Transylvania (Birkenmajer 1972b, p. 460). In addition to these two Polish astrologers, Regiomontanus had been lured to Hungary by the promise of Corvinus's generous patronage, a flourishing Renaissance court, and the promise of a secure academic position. Although Regiomontanus remained in Hungary for only 5 years before moving to Nuremberg, he produced some of his most important works while in Hungary. Hans Dorn, the most gifted instrument maker in the later 15th century, too was attracted to Hungary by the promise of Corvinus's patronage. Dorn moved to Pozsony in the late 1460s, where he met and befriended Bylica and renewed his friendship with Regiomontanus. When the university closed in 1471, Bylica moved to Corvinus's court in Buda, Regiomontanus moved to Nuremberg, and Dorn returned to Vienna. By 1476, Dorn was back in Hungary, having accepted a position at Corvinus's court in Buda. Corvinus looked to Dorn and Bylica to build an observatory in Buda and, in 1478, sent them to Nuremberg to purchase Regiomontanus's library and instruments for the observatory. Ultimately, they failed and returned to Buda empty-handed. During this time, Bylica commissioned Dorn to make a number of astrological instruments for him, including a large astrolabe, a torquetum, and a large celestial globe. The bronze globe, which Dorn completed in 1480, was the largest metal globe made in Europe before 1500 (Birkenmajer 1892; Ameisenowa 1959; Przypkowski 1962; Birkenmajer 1972a, pp. 537540; Bartha 1990; Bartha 2000). These instruments were perhaps initially intended for Corvinus's observatory, but all bear Bylica's coat of arms and were used in his astrological activities. Dorn and Bylica remained at Corvinus's court in Buda until the king's death, at which time Dorn returned to Vienna.

Bylica's career illuminates an important facet of Corvinian politics, namely the king's interest in and patronage of astrology. Corvinus's every act was calculated to improve his own image- his massive collection of illuminated manuscripts, his adoption of Renaissance styles in gardens and architecture for his palaces in Buda and Visegrád, and 
his patronage of humanists. Similarly, his patronage of astrologers was an act of selfaggrandizement. He turned to astrology because he understood it to contribute to his broader image as a Renaissance monarch. Consequently, Corvinus sought out the most gifted scholars in the astrological and astronomical sciences precisely because they played an important role in his political agenda and in constructing Corvinus's image of himself as a learned and generous king. The king's efforts to establish and support universities in Pozsony and later in Buda, along with his hope of building an observatory in Buda, further reveal the importance of astrology at the Hungarian court. All this activity indicates that Corvinus was not simply a collector of books or a patron of second-rate humanists and that Hungary was not confined to the intellectual and cultural hinterlands of Europe. Rather, Corvinus tried to construct an intellectually vibrant court that was able to attract some of the best European scholars. His success in transforming the image of the Hungarian monarchy and the court, indeed his success in constructing the ideal of a Renaissance in Hungary if not the reality in 15th-century Hungary, depended not only on his immense library or his beautiful palaces but also on the astrologers and astronomers who spent all or part of their careers at Corvinus's court.

\section{Acknowledgements}

Preliminary versions of this essay were presented at the 2006 annual meetings of the Renaissance Society of America and the History of Science Society. Audiences at both meetings raised helpful questions that improved this essay. In particular, I thank Valery Rees for her suggestions and comments on this project as it matured. I also thank Peter Barker for encouraging me to finish this article. Research for this project was generously supported by a Younger Scholar's Research Grant from the Renaissance Society of America. Finally, Anna Kozłowska in the Manuscript Department at the Jagiellonian Library offered invaluable assistance in navigating the rich collection of manuscripts in Krakow.

\section{BIBLIOGRAPHY}

Ameisenowa, Zofia

1959: The Globe of Martin Bylica of Olkusz and Celestial Maps in the East and in the West. Translated by Andrzej Potocki, Wroclaw: Wydawnictwo Polskiej Akademii Nauk.

Azzolini, Monica

2005: "Reading Health in the Stars: Politics and Medical Astrology in Renaissance Milan", in Günther Oestmann, H. Darrel Rutkin, and Kocku von Stuckrad (eds.), Horoscopes and Public Spheres. Essays on the History of Astrology, Vol. 42, Berlin: Walter de Gruyter, pp. 183-205.

Balogh, Jolán

1966: A Múxvészet Mátyás Király Udvarában, 2 vols., Budapest: Akadémiai Kiadó.

1975: Die Anfänge der Renaissance in Ungarn. Matthias Corvinus und die Kunst. Translated by Hildegard Baranyai, Graz: Akademische Druck- und Verlagsanstalt.

Bartha, Lajos

1990: “Egy Reneszánsz éggomb, mint csillagászati müszer: A Dorn-Bylica glóbusz, 1480-ból”, Technikatörténeti Szemle 18, 87-96. 
2000: "A Renaissance Celestial Globe as an Analogue Computer", in Klaus Hentschel and Axel D. Wittmann (eds.), The Role of Visual Representations in Astronomy: History and Research Practice, Frankfurt-am-Main: Deutsch, pp. 44-52.

Békés, Enikô

2004: "The Lion and King Matthias Corvinus: A Renaissance Interpretation of a Classical Physiognomic Image", Annual of Medieval Studies at the CEU 10, 77-94.

Berkovits, Ilona

1964: Illuminated Manuscripts from the Library of Matthias Corvinus. Translated by Susan Horn, Budapest: Corvina Press.

1969: Illuminated Manuscripts in Hungary. Translated by Zsuzsanna Horn, New York: Frederick A. Praeger.

Birkenmajer, Aleksander

1972a: "Le torquetum de Marcin Bylica d'Olkusz. A la lumiére de la recente decouverte du torquetum de Nicolas de Cusa", in Biskup, M., Bukowski, J., Czartoryski, P., et al. (eds.), Etudes d'histoire des sciences en Pologne, Krakow: Polska Akademia Nauk, pp. 537-540.

1972b: "Les centres de la science des astres", in Biskup, M., Bukowski, J., Czartoryski, P., et al. (eds.), Etudes d'histoire des sciences en Pologne, Krakow: Polska Akademia Nauk, pp. 437-491.

1972c: "Marcin Bylica", in Biskup, M., Bukowski, J., Czartoryski, P., et al. (eds.), Etudes d'histoire des sciences en Pologne, Krakow: Polska Akademia Nauk, pp. 533-536.

Birkenmajer, L.

1892: "Martinus Bylica von Olkusz und die astronomischen Instrumente, welche er der Krakauer Universität vermacht hat", in Anzeiger der Akademie der Wissenschaften in Krakau, UniversitätsBuchdruckerei, pp. 98-110.

Buzás, Gergely

2001: The Hercules Fountain of Giovanni Dalmata in the Royal Palace of Visegrád. Translated by Dóra Sallay, Budapest: TKM Association and the King Matthias Museum.

Bylica, Martin

n.d.: "Epistola ad Stanislaum Bylica de Olkusz de modo rectificandi genituras humanas", Bibliotheka Jagiellonska cod. 616, fol. 146.

n.d.: "Natitivates", Bibliotheka Jagiellonska cod. 3225,

1467: "Figura coeli hora institutionis Universitatis Histropolitane", Österreichische Nationalbibliothek cod. lat. 24, fol. 212r.

1468a: "Epistola", in József Teleki (ed.), Hunyadiak Kora Magyarországon, Pest: Emich Gusztáv Könyvnyomdája, pp. 282-284, 1857.

1468b: "Judicium de cometa que apparavit Anno Domini Mcccc 68", Bayerische Staatsbibliothek Clm. 9024 , fols. $107 \mathrm{r}-13 \mathrm{v}$.

1472: "Judicium de comete qui apparavit Anno Domini $\mathrm{M}^{\circ} \operatorname{cccc}^{\circ}$ 1xxij" ", Stiftsbibliothek Cod. Mellicensis $751 / 2$, fols. $319 r-25 r$.

Carey, Hilary M

1992: Courting Disaster. Astrology at the English Court and University in the Later Middle Ages, New York: St. Martin's Press.

Cicero, Marcus Tullius

1923: On Old Age. On Friendship. On Divinations. Translated by W. A. Falconer, Loeb Classical Library, Cambridge, MA: Havard University Press.

Corvinus, Matthias

1468: "Epistola ad Istropolitanam", in József Teleki (ed.), Hunyadiak Kora Magyarországon, Pest: Emich Gusztáv Könyvnyomdája, p. 351, 1855.

Csapodi, Csaba and Klára Csapodi-Gárdonyi

1969: Bibliotheca Corviniana. The Library of King Matthias Corvinus of Hungary. Translated by Zsuzsanna Horn, New York: Frederick A. Praeger. 
Dallari, Umberto

1888: I rotuli dei lettori legisti e artisti dello studio bolognese dal 1384 al 1799, Bologna: Fratelli Merlani.

Engel, Pál

2001: The Realm of St Stephen. A History of Medieval Hungary, 895-1526. Translated by Tamás Pálosfalvi, London: I. B. Tauris.

Feuer-Tóth, Rózsa

1990: Art and Humanism in Hungary in the Age of Matthias Corvinus. Edited by T. Klaniczay, Studia Humanitatis, Budapest: Akadémiai Kiadó.

Gabriel, Astrik

1969: The Medieval Universities of PÈcs and Pozsony, Frankfurt am Main: Josef Knecht.

Genuth, Sara Schechner

1997: Comets, Popular Culture, and the Birth of Modern Cosmology, Princeton, NJ: Princeton University Press.

Jervis, Jane L.

1985: Cometary Theory in Fifteenth-Century Europe, Boston: Kluwer Academic.

Kaufmann, Thomas DaCosta

1995: Court, Cloister, and City: The Art and Culture of Central Europe, 1450-1800, Chicago: University of Chicago Press.

Kren, Claudia

1977: "Planetary Latitudes, the Theorica Gerardi, and Regiomontanus", Isis 68, 194-205.

Markowski, Mieczyslaw

1973: "Die mathemaischen und naturwissenschaften an der krakauer Universität im XV. Jahrhundert", Mediaevalia Philosophica Polonorum 18, 121-131.

1989: "Martin Bylica aus Olkusz als Vermittler zwischen Johannes Regiomontanus und der krakauer astronomischen Schule in der vorkopernikanischen Zeit", Studia Mediewistyczne 26, 125-132.

Mentgen, Gerd

2005: Astrologie und Öffentlichkeit im Mittelalter. Edited by Alfred Haverkamp, Monographien zur Geschichte des Mittelalters, Stuttgart: Anton Hiersemann.

Odložilík, Otakar

1941: "Problems of the Reign of George of Podebrady", Slavonic Yearbook, American Series 1, 206-222.

1965: The Hussite King. Bohemia in European Affairs, 1440-1471, New Brunswick, NJ: Rutgers University Press.

Przypkowski, Tadeusz

1962: "Bylicas Sternglobus und die ersten neuzeitlichen Himmelskarten", Der Globusfreund 10, $103-112$.

Pułaski, Franciszek

1915: Opis 815 rękopisów. Biblioteki Ord. Krasińskich, Warsaw: Nakładem funduszu Świdzińskich.

Rady, Martyn

2004: "The Corvina Library and the Lost Royal Hungarian Archive", in James Raven (ed.), Lost Libraries. The Destruction of Great Book Collections since Antiquity, New York: Palgrave, pp. 91-105.

Regiomontanus

n.d.: "Tabula sinuum", Bibliotheka Jagiellonska.

1468: "Tabulae ac problemata primi mobilis", Bibliotheka Jagiellonska Cod. 597 DD III 59,

1467: "Tabulae directionum profectionumque", Bibliotheka Jagiellonska cod. 597,

1474: "Dialogus inter Viennensem et Craviensem adversus Gerardum Cremonensem in planetarum theoricas deliramenta", in Felix Schmeidler (ed.), Opera collectanea, Osnabrück: O. Zeller, pp. 511-530, 1972. 
Rosenthal, Earl

1978: "The Diffusion of the Italian Renaissance Style in Western Europe", Sixteenth Century Journal 9, 33-45.

Smoller, Laura Ackerman

1994: History, Prophecy, and the Stars. The Christian Astrology of Pierre d'Ailly, 1350-1420, Princeton, NJ: Princenton University Press.

Swerdlow, Noel M.

1990: "Regiomontanus on the Critical Problems of Astronomy", in Trevor W. Levere and William R. Shea (eds.), Nature, Experiment and the Sciences: Essays on Galileo and the History of Science, Dordrecht: Kluwer Academic, pp. 169-195.

Thorndike, Lynn

1936: “John Tolhopf Again”, Isis 24, 419-421.

1950: Latin Treatises on Comets Between 1238 and 1368 A.D., Chicago: University of Chicago Press. Vargha, Magda and Előd Both

1987: “Astronomy in Renaissance Hungary", Journal for the History of Astronomy 18, 279-283.

\section{NOTES}

1. 'quam tam a domino quondam Mathia Rege quam a dominis de Rozgon adeo inisus et spresus fuit et ita ad inopiam pervenit'.

2. 'pro Magistris Martino Astronomo et Galeoto'.

3. 'Huic interpretes portentorum, qui Galeotae tum in Sicilia nominabantur, responderunt, ut ait Philistus, eum, quem illa peperisset, clarissimum Graeciae diuturna cum fortuna fore'.

4. 'Anno domini 1467 cui compositioni praedictus Magister Martinus aderat et in pluribus adiutorio fuit'.

5. 'Cuicumque Mercurius fuerit in duodecima, erit magnus sapiens magnusque philosophus. Messahala in Centiloquio [sic]'. The attribution to Messahala is problematic.

6. 'Cum tuam nouerim maiestatem serenissime princeps nichil magis exoptare quam salutem tuorum regnorum quorum curam et gubernationem deus omnipotens ad tempus tuis demandauit manibus decrevi ego iudicium rerum futurarum Cometis qui praesenti anno in Septembri apparuit adiutus dotissimorum astrologorum sentencßs atque annactis experiencÿs tue Sreenitatis describere'.

7. At least six copies of this text survive. They share the same general interpretive contours and conclusions. Unless otherwise noted, all quotations come from the copy at the Bayerische Staatsbibliothek, Munich, clm 9024, ff. 107r-113v.

8. 'nontamen praedico futura accendentia Maiestatem tuam sic verum eciam mortem celerum sceleratissimo heresiarche Georgio de Podabrad qui se pro rege bohemie gerit Romane ecclesie ac ortodoxe fidei hoste acerrimo. Cum quo tua Majestatis bellum pro fide katholica anno praesenti incepti agere'.

9. 'cometes circa principium leonis primum apparuit Iovi. $2 \mathrm{~m}$ longitudinem coniunctus. qui postea totum signum leonis ac totum signum virginis motu suo proprio infecit'.

10. 'Sic et hunc cometem nostrum sine dubio terre motus sequetur in locis signo leonis suiectis'.

11. 'Item $2 \mathrm{~m}$ homerum et hali comets in leone significat bella inter reges et magnam sanguinis effusionem'.

12. 'condampnatus hereticus Georgius de Bodabrad quii pro rege Bohemie gerit cuius ascendens hora coronacionis eius signum leonis possederat ... et Rokizana bohemorum seductor per hunc cometem videlicet interficietur'.

13. 'In causis belli planete superiores fort sicantur in electione, sicut $\hbar$ 2 0 o'.

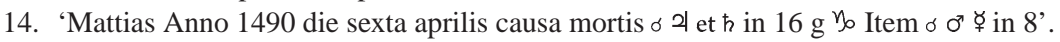

